\title{
EDITORIAL Tribute to a Leading Personality of World Horticultural Science
}

\author{
Radu E. SESTRAS
}

\begin{abstract}
Following the proposal of Academic Council of Horticulture Faculty, the Senate of University of Agricultural Sciences and Veterinary Medicine Cluj-Napoca accepted nominee Professor Jules Janick for "Doctor Honoris Causa" award. The title was awarded in festive ceremony on September 30, 2010. Jules Janick, Professor at Purdue University has a long and distinguished career devoted to horticulture in all its facets. In horticultural research, he has made important advances including the genetics of sex determination including the synthesis of heteromorphic sex chromosomes, fireblight resistance, cleistogamy, cucurbitacins, artemisisin production, anthocyanin pigmentation, as well as in vitro metabolite production from somatic embryos and the production of synthetic seed. In crop improvement, he has been associated with the release of 21 scab-resistant apple cultivars, three pear cultivars with tolerance to fireblight, delayed-bolting arugula, crack resistant tomato, and the first release of a pelargonium cultivar from somaclonal variation. Professor Janick has made contributions to the historical aspects of horticulture and explored the relation of art and horticultural technology with special studies on the iconography of Rubus, Cucurbitaceae, and Solanaceae, opening up a new approach to the study of plant diversity, origins, cultivar evolution, and diversity. Professor Janick has been a prolific author and editor in horticulture. He was the editor of HortScience and editor of the Journal of ASHS. He is the founder and editor of both Horticultural Reviews and Plant Breeding Reviews. Since 2002 he has been the science editor of Chronica Horticulturae (ISHS). Janick has edited and produced six proceedings of New Crops symposia since 1990 that have had a deep impact on new crop information. The development of a new crop website has become a major world resource for information on crops. He is the author of the texts Horticultural Science, Plant Science: An Introduction to World Crops, and the co-editor of a series of monographs on fruit breeding. So far in his career Janick has written or edited 140 volumes, a truly prodigious achievement; he has taught numerous courses in genetics, plant breeding, and horticulture. Professor Janick has become one of the best known personalities of world horticulture. His credo has been that advances in horticulture throughout the centuries represent some of the greatest human accomplishments for the betterment of humanity.
\end{abstract}

In Romania, the title of "Doctor Honoris Causa" is the highest academic distinction given to personalities with exceptional achievements in scientific and academic plan, or who have unique contributions to the development of science. Professor Jules JANICK was nominated for the title of "Doctor Honoris Causa" following a four step process:

September 7, 2009. Professor Radu E. SESTRAS, Dean, Faculty of Horticulture, University of Agricultural Sciences and Veterinary Medicine Cluj-Napoca, proposed to nominee Professor Jules JANICK for "Doctor Honoris Causa" award in Horticulture and Landscape Chair meeting. The proposal was accepted by vote of members, and Head of Chair, Professor Viorel MITRE, sent the proposal to the Bureau of Academic Council of Horticulture Faculty.

September 15, 2009, Bureau of Academic Council of Horticulture Faculty accepted the proposal.

September 24, 2009, Dean SESTRAS presented the proposal to Academic Council of Horticulture Faculty. After acceptance, the proposal was sent to the Rector Doru PAMFIL and the Senate of University of Agricultural Sciences and Veterinary Medicine Cluj-Napoca.
April 1, 2010. The Senate of University of Agricultural Sciences and Veterinary Medicine Cluj-Napoca accepted nominee and decided to grant the title at International Symposium of UASVM occasion on September 30, 2010.

The Doctor Honoris Causa ceremony honouring Professor Jules JANICK

was held in the Aula Magna of the University of Agricultural Sciences and Veterinary Medicine Cluj-Napoca, Romania, on September 30, 2010, 13.00-14.00. The committee members were:

Doru PAMFIL - UASVM Rector

Liviu Al. MARGHITAS - UASVM President

Cornel CATOI - Vice Rector

Sevastiţa MUSTE - Vice Rector

Augustin VLAIC - Vice Rector

Ioan ROTAR - Dean, Faculty of Agriculture

Radu E. SESTRAS - Dean, Faculty of Horticulture

Vioara MIRESAN - Dean, Faculty of Animal Breeding and Biotechnology

Ioan Stefan GROZA - Dean, Faculty of Veterinary Medicine 


\title{
LAUDATIO
}

\author{
Radu E.SESTRAS
}

Today we are celebrating an exceptional and memorable moment when our University and Faculty of Horticulture from Cluj-Napoca pay homage to a leading personality in world horticulture, Professor Jules JANICK, from the Department of Horticulture and Landscape Architecture, Purdue University.

The grant by the Senate University of Agricultural Sciences and Veterinary Medicine Cluj-Napoca of Doctor Honoris Causa title to Professor Jules JANICK is also an important academic recognition, but also a moment of historic significance, the homage of a scientific personality who has dedicated his life work in one of the finest and beautiful agricultural and biological sciences - Horticulture!

It is our great pleasure to be present today, in the Aula Magna of our University, along with outstanding scientific personalities from Romania and abroad, in a celebration of a unique event in which we celebrate an illustrious 'magister' of the world, a true titan of horticulture.

A man who made from a profession, a career, which had force and bring a special contribution in the last 50 years to the worldwide development and recognition of horticultural sciences. A man who through his efforts has a positive influence not only on humanity and horticulture, but in all areas of biology, and manages to lead horticulture with passion to expand science, knowledge, and art.

In this exceptional context, we are happy to recall some parts of biographical and professional references of Professor Jules JANICK who was born in New York City, on March 16, 1931.

He married Shirley REISNER in 1962 and they have two children: Peter (born 1953) and Robin (b. 1956) and four grandsons.

Dr JANICK has devoted his long career to horticulture in its many aspects, both nationally and internationally.His career is based on research contributions in genetics and breeding, to undergraduate and graduate education, and in promoting the interrelationship of horticulture, art, and human culture.

His lasting contribution to horticulture will be found in the achievements of his students, the germplasm of his fruit and vegetable releases, his contributions to the horticultural literature in both science and culture, and his achievements in organizing the accomplishments of horticulturists and horticulture in an archival form.

Dr JANICK is considered one the outstanding personalities in world horticulture based on his many publications and achievements in horticulture including: 140 volumes authored or edited; 400 papers; and 50 book chapters. He founded and still edits Horticultural Reviews (38 volumes) and Plant Breeding Review (34 volumes). His releases include scab resistant apples ('Prima', 1970;
'Priscilla', 1972; 'Priam', 1974; 'Sir Prize', 1975; 'Jonafree', 1979; 'Redfree', 1981; 'Dayton', 1988; 'Williams' Pride', 1988; 'McShay', 1988; 'Enterprise', 1993; 'GoldRush', 1993; 'Pristine', 1994; 'Primiere', 1995; 'Primevere', 1996; 'Scarlet O'Hara', 2000; 'Sundance', 2002; 'Pixie Crunch', 2002; 'CrimsonCrisp', 2005; 'WineCrisp', 2009); fireblight tolerant pears ('Honeysweet', 1976; 'Green Jade', 2002; 'Ambrosia', 2005); tomato ('Santa Rita', 1963); Geranium ('Velvet Rose", 1976); Salpiglossis ('P1-P8 germplasm', 1982); and arugula ('Adagio', 2005). He is known for his research in plant breeding genetics, tissue culture, and horticulture; his extraordinary skills as an editor of journals and publications; his career in teaching, lecturing, and helping students (students or PhD students of Professor JANICK are well-known in horticulture, e.g. W.B. SHERMAN, E.C. TIGCHELAAR, R.L. FERY, R.M. SKIRVIN, R.L, BELL, R.L. SCORZA, A. FIGUEIRA, and J. F.S. FERREIRA). His website NewCROP, a compendium of information of horticultural and world crops receives over 26 million hits annually.

Recently, Dr JANICK has become a leading figure in the field of crop iconography. His online courses on the "History of Horticulture" and "Tropical Horticulture" can be accessed by anyone on the "NewCROP" website. He is known by a generations of students as a result of his textbook "Horticultural Science and Plant Science: An Introduction to World Crops". In the last eight years, he has energized Chronica Horticulturae, a publication of the International Society for Horticultural Science which has invigorated this organization which now has over 7000 members. He has recently co-edited the 954 page Encyclopedia of Fruit \& Nuts which has become an instant classic. Dr. JANICK, a former President of the "American Society of Horticultural Science", has recently been honoured by being inducted into its "Hall of Fame".

On this occasion, Jay AKRIDGE, Dean of the Faculty of Agriculture at Purdue University, said: "Dr. Jules JANICK, Horticulture and Landscape Architecture, has been named to the American Society for Horticultural Science Hall of Fame - the society's highest honor. During his 58 years of service to Purdue, Dr. JANICK has distinguished himself as a teacher of horticulture and researcher in genetics and breeding. He is renowned for his wide-ranging activities in horticultural science, encompassing both basic and applied scientific research in areas such as orchard and forest trees, fruits, vegetables and ornamental plants. Jules JANICK was among the first horticultural scientists to employ biotechnological propagation techniques, and he was a pioneer researcher in the field of somatic embryogenesis and synthetic seed technology. He join a distinguished roster of others so honored in the past, including, among others, Martin BUKOVAC, Charles RICK Jr., 
Luther BURBANK, Liberty Hyde BAILEY, and Gregor MENDEL".

Among his numerous recognitions are the Wilder award of the American Pomological Society, Corresponding Member of the Italian Academy of Agriculture, and honorary degrees from the University of Bologna, Technical University of Lisbon, and the Hebrew University of Jerusalem.

But above all, Dr. JANICK is an advocate for horticulture. Jules JANICK describes horticulture as "food for body and soul". His theme as ASHS President was that "our lives depend on horticulture". His credo has been that "advances in horticulture throughout the centuries represent some of the greatest human accomplishments for the betterment of humankind". Based on these considerations, the title of Doctor Honoris Causa to Dr Jules JANICK is a welcome recognition and a great celebration for the entire academic community of our university and Cluj-Napoca academic centre.
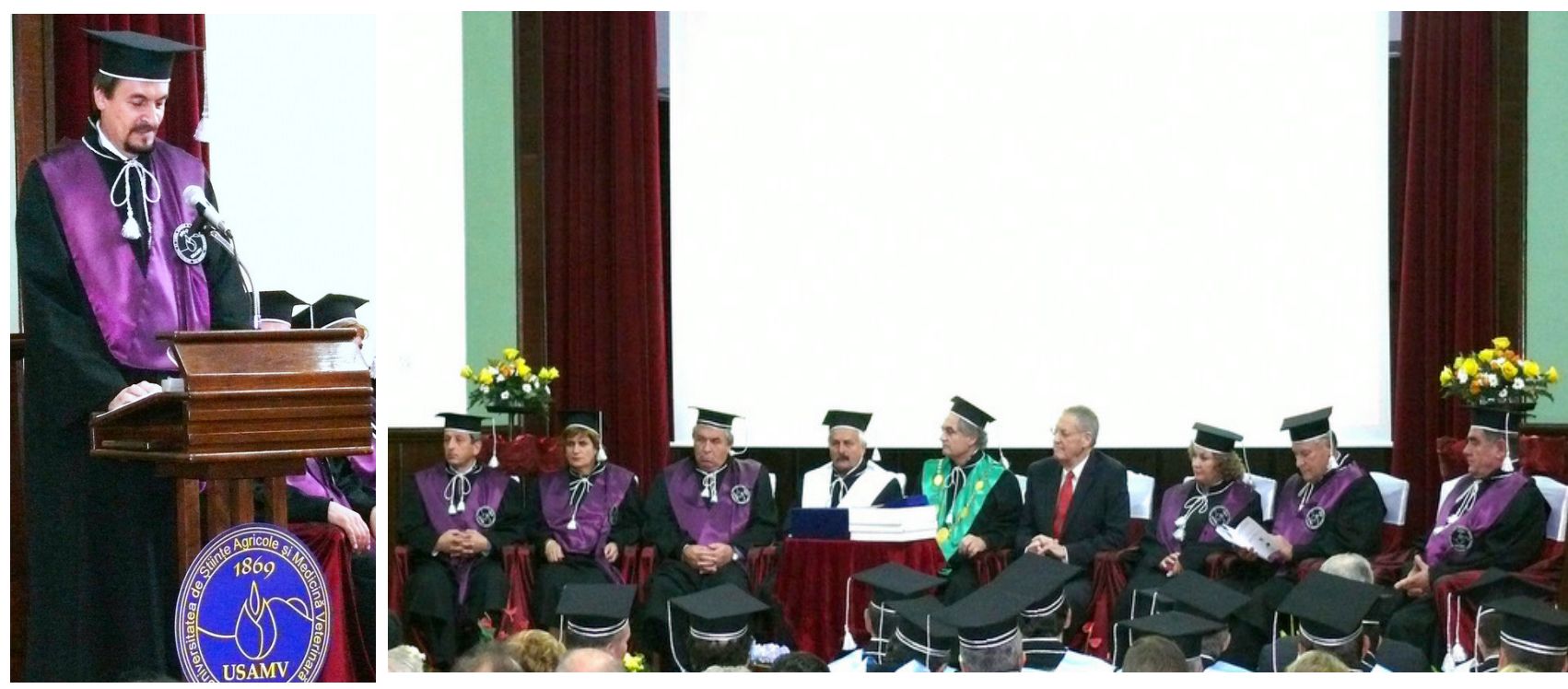

Dean Sestras presenting "Laudatio" and Doctor Honoris Causa Committee Members
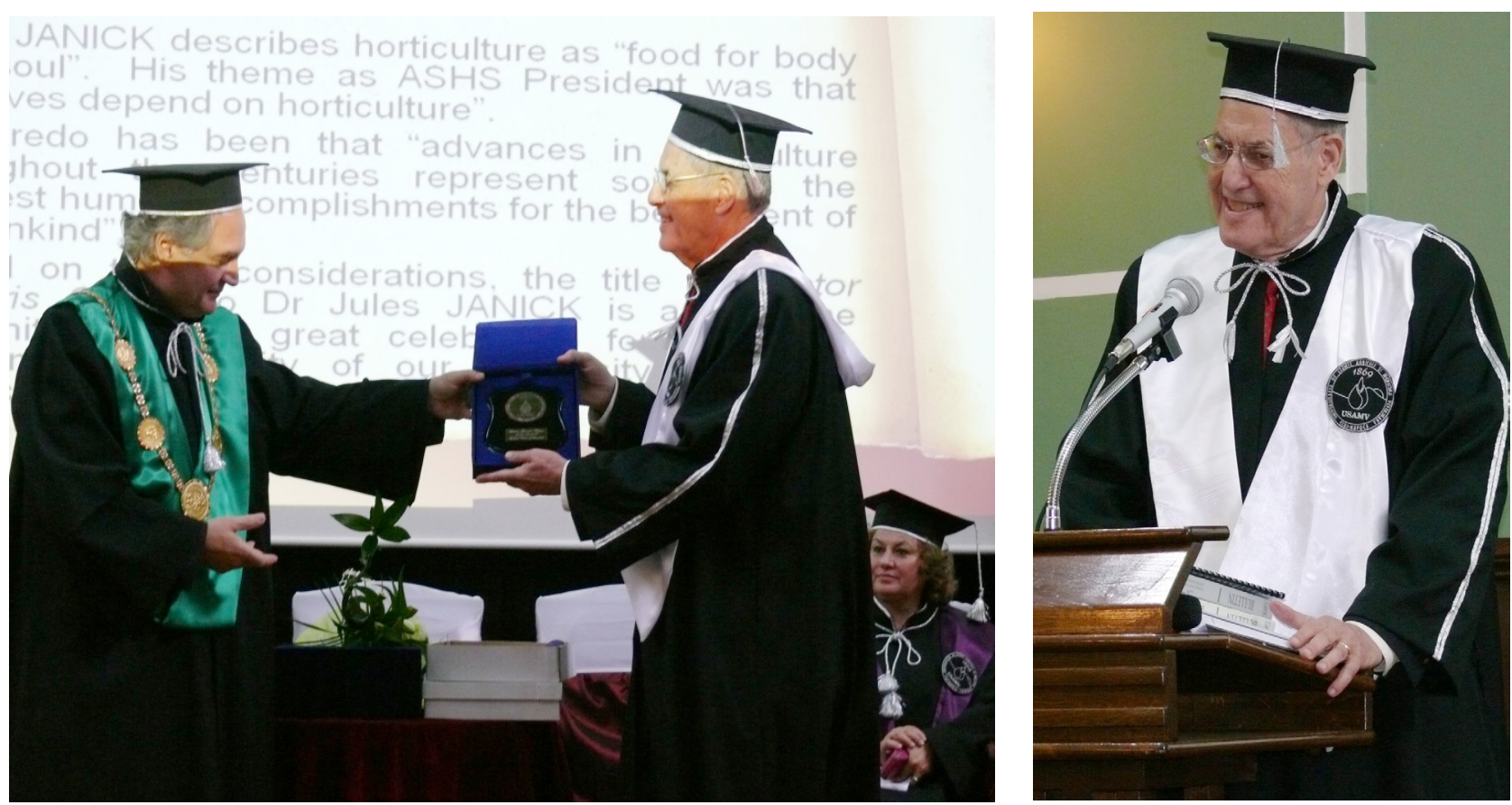

Rector Pamfil presented the title of Doctor Honoris Causa and medal to Professor Janick Professor Janick giving a speech after receiving Doctor Honoris Causa title 


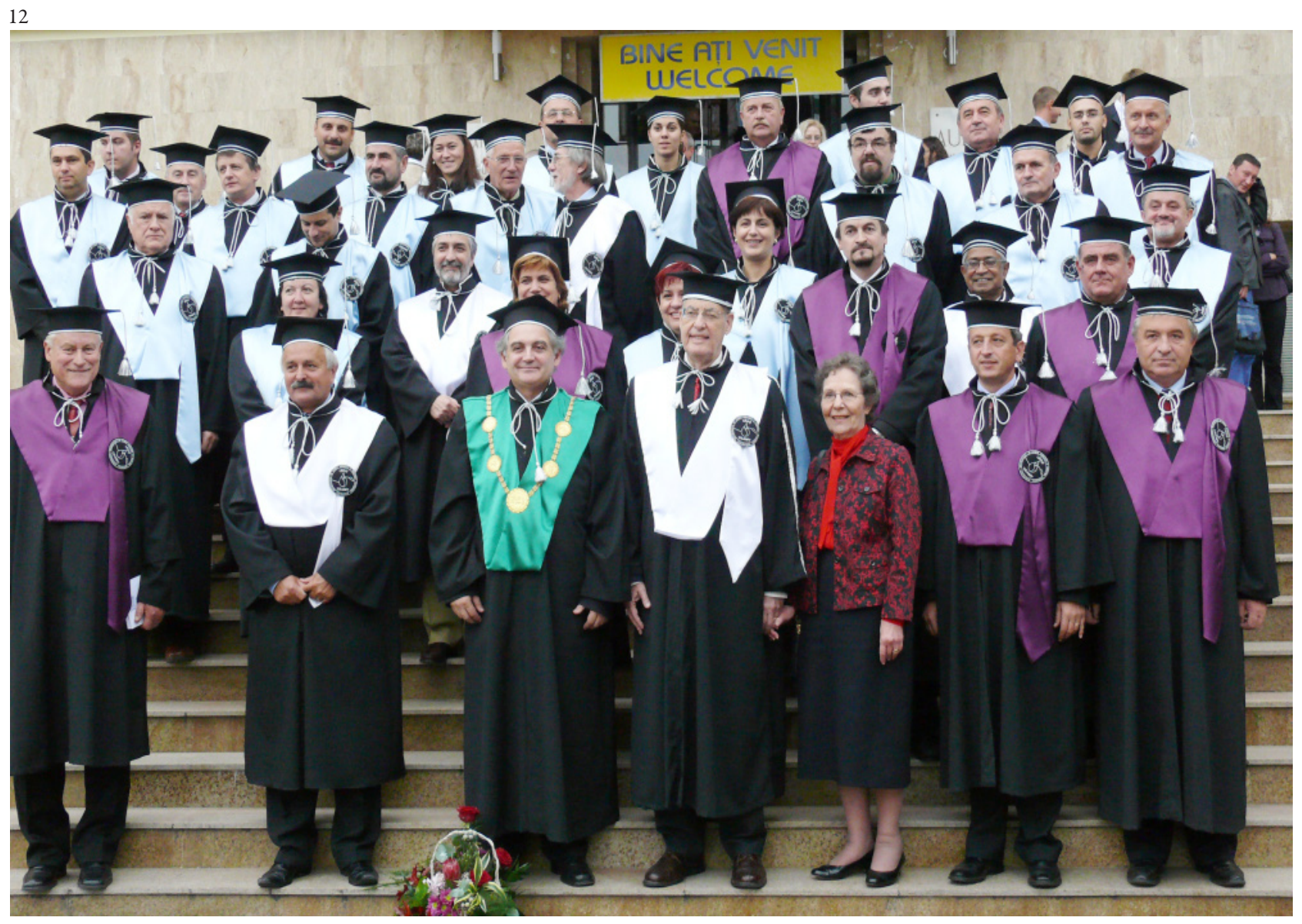

In the front of "Aula Magna" building with Senators, Professors, and Honoree

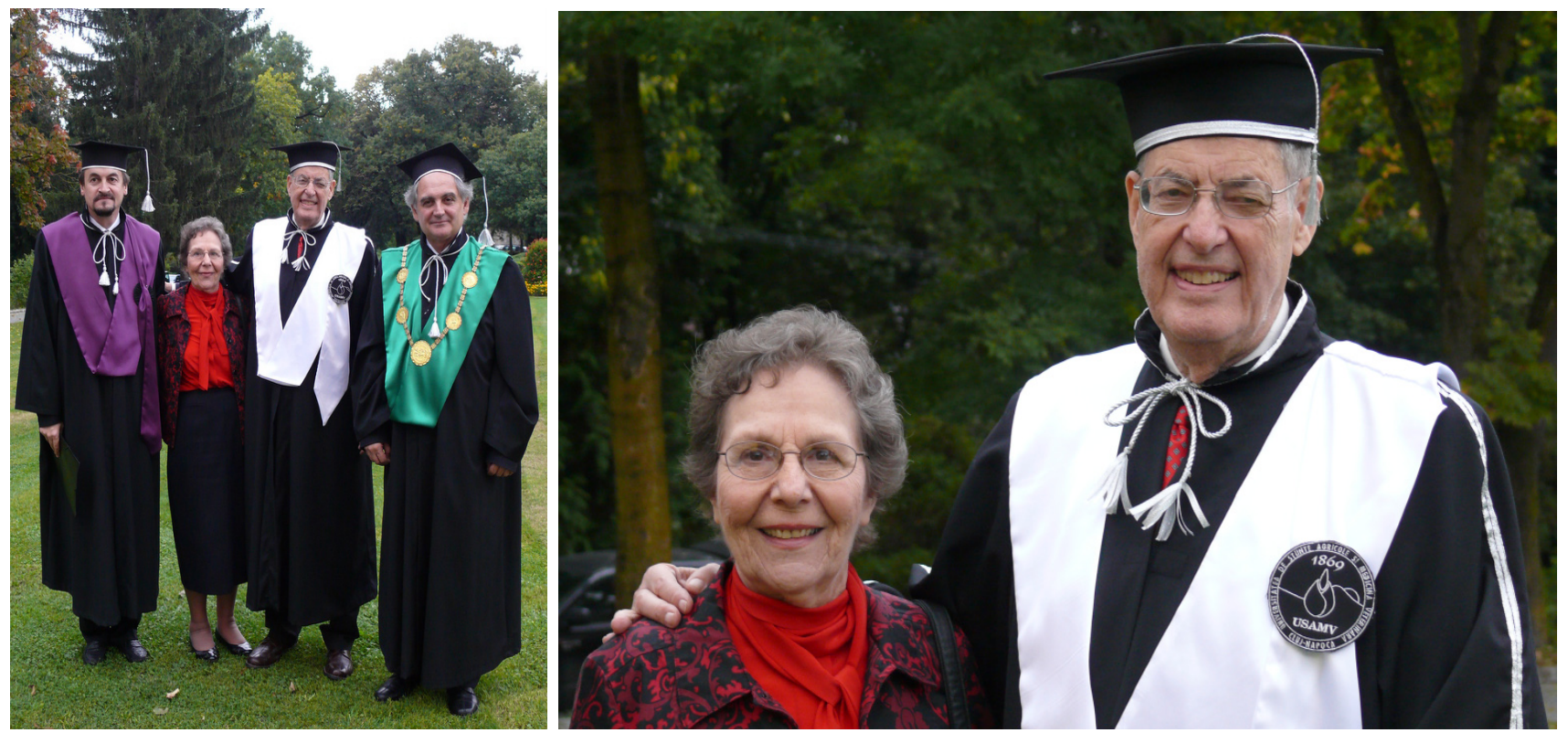

Professor Janick and his wife, Shirley, Rector Pamfil (right) and Dean Sestras (left) 


\section{Remarks of Professor Jules Janick upon receiving Doctor Honoris Causa}

It gives me extreme pleasure to accept the honor of receiving the highest academic title, Doctor Honoris Causa, of the University of Agricultural Sciences and Veterinary Medicine Cluj-Napoca, that you have graciously bestowed on me. I accept this award on behalf of horticulture and horticultural scientists the world over. I consider this award as a recognition of the importance of horticulture to people everywhere, who strive to live a healthy life based on delicious and wholesome fruits, nutritious vegetables, and zestful culinary herbs; who are moved by the beauty of flowers, the shade of trees, and the inspiration of landscapes; and who are who are benefited by the healing power of herbs and their derivatives.

Horticulture is more. Its origins are intimately associated with the history of humanity. It represents the origins of agriculture - the mother of science. It long has been extolled in song, poetry, prose, and art. Indeed horticulture provides food for the body and food for the soul.

There is still more. Horticulture is a great industry and transforms sun and water and soil into commercial products that we use every day, for nourishment, enjoyment, and sustenance. It provides a livelihood for billions of people. It is also a science worthy of respect. The greatest paper in biology, written by a horticulturist named Gregor MENDEL about the transmission of characters in the garden pea, led to the unifying science of genetics. The science of horticulture is presently continues to undergo a renaissance by the unraveling of the gene and the genome.

Throughout world history, all cultures have extolled the benign aspects of gardening and the joys of horticulture. We use horticultural allusions for our highest ideals: The prophets Isaiah and Micah urged us to heat our swords into plowshares and our spears into pruning hooks and study war no more. The ancient Persians considered Paradise and Gardens as synonyms.

Yet due to a combination of circumstances our profession finds itself in the vortex of controversy and tension. The aphorisms extolling horticulture have been drowned out by chorus of bitter epithets of a different hue altogether: Frankenfoods, Pesticide Poisons, Fertilizer Contamination, Desertification, Factory Farms, Drug Lords, and Plantation Exploitation.

Let me briefly review some of the great controversies that face horticulture ${ }^{1}$ :

\section{Organic versus Conventional Horticulture}

In the recent past organic horticulture was something to be avoided. Tourists were warned not to eat uncooked food, not to drink the water, and at all costs to avoid raw salads when visiting poor countries because of the threat of disease from "night soil." It may still be good advice in many parts of the world. The organic movement has reversed this bias and told us to instead to be wary of unblemished, produce due to the probably used of chemical pesticides and inorganic fertilizer. Wormy fruit or vegetables, instead of being a sign of poor management, have become a sign of freedom from harmful chemicals. The world continues to be confused by the terms, organic vs inorganic, natural vs. synthetic, and pesticide vs. medicine. Horticulture needs to navigate between these two opposing rocky shoals.

\section{Biotechnology and Traditional Breeding}

The fusion of biology and technology has been considered the crown jewel of horticultural science. One of the great achievements of the 20th century has been the ability to achieve genetic improvement using genes from distantly related species through sexual recombination; the ability to obtain new cultivars from old genes. A great advances in the latter part of the 20th century, transgene technology sometimes known as genetic engineering, has been based on the dazzling discovery that genes could be extracted from any species and inserted into another, overcoming the restriction of sexual barriers. This was hailed as truly a wonder of science and we entered the brave new world of biotechnology. To our shock we learned that there were many who considered that transgene technology was dangerous, unnatural, anthema. Their emotional arguments seemed persuasive enough to result in a biotechnology ban in Europe and elsewhere. Where does modern horticulture navigate?

\section{Germplasm Sharing and Patenting}

One of the common beliefs of plant breeders and traditional horticulturists was that the world heritage of germplasm was a common resource available to all of humanity. This assumption was shattered when various countries decided that germplasm was a natural resource that could be exploited. In addition the concept that unique combinations of genes could be considered an invention and patentable soon initiated a conflict between national rights, farmers' rights and intellectual property rights. Horticultures find itself in the center of this controversy.

\section{Herbal Medicine versus Designer Drugs}

While the medicinal and healing effects of certain horticultural plants have been the basis of medicine for over 5000 years, and plant derived chemicals are the basis of the 
14

majority of medicine, the relation between herbal medicine and modern medicine still is unresolved. Skeptics consider the lack of support for herbal medicine as a plot by the drug industry while the drug industry considers herbal medicine the purview of the witch doctor, shaman, and conjurer. There is a problem. To our shock we learned that there were many who considered that transgene technology was dangerous, unnatural, anthema. Their emotional arguments seemed persuasive enough to result in a biotechnology ban in Europe and elsewhere. Where does modern horticulture navigate?

\section{Globalization versus National Protection}

The advances in postharvest horticulture, protected culture, and intercontinental shipments have given the lie to the concept that horticulture products must be seasonal in nature. The globalization of horticulture has disoriented many horticultural industries. Transcontinental shipments of fruits and flowers have become bonanzas for some and disasters for others. The fight over subsidies, tariffs, and protectionism (often based on questionable quarantines) has been disorienting to many horticultural industries and led to trade wars and food fights. Whose side are we on?

\section{Horticulture and Economic Development}

Horticulture was long been considered a luxury part of agriculture, too trivial to be taken seriously when the world was in need of calories or protein, while our claim to be the source of vitamins, minerals, and nutraceuticals has long been ignored. We have insisted that horticulture is a key to economic development. Horticulture continues to fight to find its place on the table.

\section{Horticulture as an Academic Discipline}

The role of horticulture in academia is under attack. Where horticultural science was once considered a corner- stone of agricultural education, the very concept of agriculture as a scientific discipline is being questioned. Plant physiologists have morphed into plant biologists, and horticultural scientist are being morphed into plant scientists. Do we fight or join? Public institutions have been assured that applied research will be taken over the private sector but this trend has resulted in the decimation of public plant breeding and the destruction of once proud extension services. Horticulturists rightly feel threatened and confused. What dare we do about this trend?

We live in interesting and exciting times. I will concede that these controversies are not black and white choices and that compromises are needed. But these controversies are a sign of the politicization of science and reflect fear of the unknown. Horticulture, after all reflects both ancient practices and new technologies. Horticulture is conservative and radical at the same time and finds itself at the nexus of the current controversy between science and society. Our profession and our universities must squarely face these issues and come up with appropriate answers to improve the living conditions of all people in all places. We as horticultural scientist cannot retreat from these problems. We horticulturists by nature would probably prefer to cultivate out own garden and stay out of the public eye. However if we do not get involved and offer our professional expertise on these issues, the field will be left open to all sorts of self-appointed experts, media spin doctors, and self-serving lobby group that will influence decision makers. I suggest that horticultural scientists by our training are well positioned to offer leadership in resolving these controversies and provide a link between the scientific community and ordinary citizens. The more we engage in these issues, the more the real facts will be disclosed, and the greater is the chance that wiser and better decisions will be pursued.

'Based on "Horticulture at the Crossroads". Chronica Horticulturae 45(1):3-4 (2005). 